\title{
Biocontrolled soil nutrient distribution under the influence of an oxalogenic-oxalotrophic ecosystem
}

\author{
Sophie Pons • Saskia Bindschedler • David Sebag • \\ Pilar Junier • Eric Verrecchia • Guillaume Cailleau (1D
}

Received: 14 June 2017 / Accepted: 12 January 2018 / Published online: 30 January 2018

(C) The Author(s) 2018. This article is an open access publication

\begin{abstract}
Background and Aims The oxalate-carbonate pathway (OCP) has been observed in acidic tropical soils with low alkaline cation content where compartments are transient and fed by the rapid turnover of organic matter. By acting on edaphic parameters, the OCP may influence soil nutrient distribution. This study aims at assessing the influence of the OCP on soil nutrients within an agroforestry system associated to oxalogenic iroko trees. Methods Soil nutrient distribution was studied in a $30 \mathrm{~m}$ long and $1 \mathrm{~m}$ deep transect starting at the iroko tree towards the vegetation surrounding it.

Results Processes controlling nutrient distributions varied with both distance and depth. The tree drastically impacted edaphic variables, in the first instance $\mathrm{pH}$.
\end{abstract}

Responsible Editor: Honghua He

Electronic supplementary material The online version of this article (https://doi.org/10.1007/s11104-018-3573-1) contains supplementary material, which is available to authorized users.

S. Pons · D. Sebag · E. Verrecchia $\cdot$ G. Cailleau $(\bowtie)$ Biogeoscience Laboratory, Institute of Earth Surface Dynamics, University of Lausanne, Lausanne, Switzerland

e-mail: guillaume.cailleau@gmail.com

S. Bindschedler · P. Junier

Laboratory of Microbiology, Institute of Biology, University of

Neuchâtel, Neuchâtel, Switzerland

S. Bindschedler

Department of Environmental Microbiology, Helmholtz Centre

for Environmental Research - UFZ, Leipzig, Germany
Changes in $\mathrm{pH}$ generated gradients of calcium and magnesium, both of the exchangeable and the total fraction. In contrast, total phosphorus and potassium distribution were mostly influenced by depth.

Conclusions This downward gradient fits the "plant cycling model" that explains the effect of vegetation on the recharge of soil nutrients. This is the first example of the effect of the OCP on soil nutrient distribution. Considering that the OCP is not restricted to the iroko tree, this study highlights a more general pattern of forest dynamics developed on highly weathered tropical soils.

Keywords Gradient · Nutrient dynamics · Oxalate · Soil $\mathrm{pH} \cdot$ Tropical ecosystem

\author{
D. Sebag \\ Normandie Univ, UNIROUEN, UNICAEN, CNRS, M2C, Rouen, \\ France \\ D. Sebag \\ HSM, LMI PICASS'EAU, IRD, Université de Montpellier, \\ Montpellier, France
}




\section{Introduction}

Ferralsols represent about $7.5 \%$ of the ice-free area of the world (Soil Survey Staff 1999). These tropical soils spread over three continents, but are mostly found in Africa and the Amazon basin. They develop over long time spans (from at least 0.1 and up to 20 million years; Lanfranchi and Schwartz 1990) under relative geomorphological stability, combined with warm-humid conditions and a very gentle slope. These conditions lead to intense weathering and leaching. This pedogenesis (mainly ferralitization) leads to enrichment of aluminium $(\mathrm{Al})$, silicon $(\mathrm{Si})$, and iron $(\mathrm{Fe})$, while other cations such as sodium $(\mathrm{Na})$, magnesium $(\mathrm{Mg})$, potassium $(\mathrm{K})$, and calcium $(\mathrm{Ca})$ are leached from the solum. These soils are consequently known to be highly acidic and non-valuable for agricultural purposes. In this context, an often overlooked pedogenic process called the oxalatecarbonate pathway (herein referred to as OCP; Braissant et al. 2004; Cailleau et al. 2011; Verrecchia et al. 2006) can lead to the mitigation of ferralitization in relatively short timespans (likely to be less than a century), by increasing soil $\mathrm{pH}$ and storing significant amounts of both calcium and carbon in the soil (Cailleau et al. 2004). Briefly, in the OCP, oxalate produced by plants and fungi is oxidized by soil oxalotrophic bacteria. Bacterial oxalotrophy is further supported by bacterial-fungal interactions (Martin et al. 2012), leading to a local increase of soil $\mathrm{pH}$ that eventually allows calcium (and magnesium) carbonate to precipitate (Verrecchia et al. 2006). For this reason, ecosystems harbouring OCP properties can also be referred to as "oxalogenicoxalotrophic ecosystems". To summarize, the OCP is a process that allows for the transformation of sunlight into accumulations of pedogenic carbonate, a relatively inert compound with a residence time of $10^{2}$ up to $10^{6}$ years (Cailleau et al. 2011; Retallack 1990). In other words, this pedogenic process is akin to natural liming.

The effect of leguminous plants on soil $\mathrm{N}$ content through symbiotic association with $\mathrm{N}_{2}$-fixing bacteria is a well-known example of the impact of microbial symbioses with plants upon soil (Hoogmoed et al. 2014; Resh et al. 2002). In addition, the type of plant directly influences litter quality and, in turn, soil biogeochemistry (Augusto et al. 2002; Hobbie et al. 2006) and structure of the soil microbial community (Ettema and Wardle 2002; Saetre 1998). These two parameters, litter composition and microbial community structure, are interconnected to the build-up of plant species-specific soil organic matter (Ehrenfeld 2003; Potter and Woodall 2014; Vesterdal et al. 2013). The latter is of growing interest because it is directly linked to the carbon cycle and thus to climate mitigation.

The spatial distribution of nutrients in a soil under the impact of plants is a general concern of ecology and environmental sciences. Several studies have dealt with the horizontal patterns of nutrient distributions in soils in relationship to the presence of specific tree species. For instance, in savannahs, which are composed of grasslands with scattered trees, studies have emphasized decreasing gradients of soil fertility indicators, such as total N, P, K, and $\mathrm{Ca}$ toward the open grassland (Belsky et al. 1989; Kellman 1979). This pattern was also observed in semi-arid environments under shrubs influence (Li et al. 2007; Wezel et al. 2000). Other studies have discussed vertical (depth) patterns of nutrient distributions in relationship to the presence of plants (Jobbágy and Jackson 2001), emphasizing two main counteracting mechanisms: leaching, which tends to deplete nutrients from the topsoil, and plant cycling, which tends to accumulate nutrients at the topsoil.

The iroko tree (Milicia excelsa) is known from the beginning of the last century to be associated to calcium carbonate (in its tissues as well as in the close surrounding soil; Adriaens 1934; Carozzi 1967). These carbonate accumulations are unexpected, considering local environmental conditions (low cation content and acidic soils). During the last decade, the OCP has been pointed out as being responsible for the formation of calcium carbonate related to the iroko tree. Basically, the scenario of how the OCP works is described by Cailleau et al. (2011) and was completed by Martin et al. (2012) concerning the crucial role of fungi. In short: i) as a result of photosynthetic activity, calcium oxalate accumulates in the iroko tissues; 2) a flux of oxalate-bearing organic matter to the soil is constituted; 3 ) after biodegradation of leafy and woody tissues, the oxalate crystals are oxidized through the concomitant action of fungi and oxalotrophic bacteria; 4) with time, the oxalotrophic activity results in an increase of soil $\mathrm{pH}$ (Braissant et al. 2004) and finally to calcium carbonate accumulations when conditions are favourable (i.e soil $\mathrm{pH}>8.4$, stability $\mathrm{pH}$ of calcite in environmental conditions, availability of $\mathrm{Ca}^{2+}$ ).

The presence of an oxalogenic-oxalotrophic ecosystem in a previously acidic environment drastically changes soil physicochemical parameters, mainly its $\mathrm{pH}$. However, until now, the effect of these changes on 
soil nutrient distribution has not been assessed. A strong variation of nutrient concentrations is expected due to the drastic changes in physicochemical soil conditions. Hence, the aim of this study is to assess the influence of the OCP on soil nutrients within an agroforestry system associated with iroko trees (Milicia excelsa) in Cameroon, Africa. For this purpose, soil parameters such as $\mathrm{pH}$, total organic carbon (TOC), and nutrient concentrations ( $\mathrm{N}, \mathrm{P}, \mathrm{K}, \mathrm{Ca}$, and $\mathrm{Mg}$ ) were measured as a function of the distance to a mature iroko tree along a $30 \mathrm{~m}$ long (horizontal effect) by $1 \mathrm{~m}$ deep (vertical effect) transect. For this study, a coffee (Coffea arabica) agroforestry system was chosen because it represents a widespread traditional agricultural crop in tropical Africa. This study contributes to the understanding of the possible mechanisms involved in nutrient distribution in the particular case of oxalogenic-oxalotrophic ecosystems.

\section{Material and methods}

Environmental settings

This study was conducted in the Noun province, West Cameroon. The local climate is tropical humid, characterized by two distinct seasons, a humid one from March to November, and a dry one from November to March. The mean annual temperature is above $20{ }^{\circ} \mathrm{C}$ and the average annual rainfall ranges from 1500 to $2000 \mathrm{~mm} /$ year (Olivry 1976). The study site is located in a plain at approximately $720 \mathrm{~m}$ a.s.1. near the Mbam River, situated at $300 \mathrm{~m}$ to the east. The geological substratum is comprised of migmatites and gneiss according to the literature (Le Maréchal 1976).

Vegetation in West Cameroon is composed of primary or secondary semi-deciduous rainforests (Brenac 1988), where intensive coffee cultures are gaining ground. In Africa (including Cameroon), intensive logging by the opening of tracks is a key-driver leading to the transformation of forest range to agricultural areas and savannah. This is the case in the Mambicham area where only some relict plots of tropical forest lie along the border of traditional agroforestry systems. At the study site and close to the Mambicham village $\left(5^{\circ} 50^{\prime}\right.$ $49^{\prime \prime} \mathrm{N}, 11^{\circ} 13^{\prime} 35^{\prime \prime} \mathrm{E}$ ), an old iroko tree (diameter at breast height - DBH - of ca. $160 \mathrm{~cm}$ ) stands in a coffee plantation for at least 150 years.
Soil sampling

Five soil profiles (named station A to E) were dug along a $30 \mathrm{~m}$ long transect from the iroko trunk, down to a depth of $1 \mathrm{~m}$, and at increasing distances from the iroko tree: $0.5 \mathrm{~m}(\mathrm{~A}), 2.5 \mathrm{~m}(\mathrm{~B}), 8 \mathrm{~m}(\mathrm{C}), 15 \mathrm{~m}$ (D), and $30 \mathrm{~m}$ (E). The transect was oriented perpendicular to the gentle slope $\left(<1^{\circ}\right)$ toward the Mbam River, $4 \mathrm{~km}$ downwards. The soil at A corresponds to a Mollic Ferralsol Calcaric (IUSS 2006). The soil profiles at B to E were identified as Pisolithic Plinthosol Ferric with very few variations (Fig. 1).

Samples were collected in triplicates from three different sides of the dug soil profile: the face closest to the iroko and the two adjacent faces. Samples were taken at the following depths: $5,10,15,20,30,50,75$, and $100 \mathrm{~cm}$. Soil profile locations were chosen in order to have three coffee plants at less than $1 \mathrm{~m}$ to ensure conditions as similar as possible. Particular attention was paid to prevent the influence of any other oxalogenic-oxalotrophic ecosystem (as defined by Cailleau et al. 2011, 2014) from at least a distance of $15 \mathrm{~m}$.

Soil samples (250-400 g) were air-dried during fieldwork and, once brought back to Switzerland, oven dried at $45^{\circ} \mathrm{C}$ over 2 weeks to be sure they were sufficiently dried. Soil samples were sieved at $2 \mathrm{~mm}$ and a part of this fraction was powdered with an agate mortar.

\section{Soil physicochemical analyses}

Soil grain-size distributions were performed with a nonpowdered $>2 \mathrm{~mm}$ fraction after calcium carbonate removal using 3.3 M hydrochloric acid (Pansu and Gautheyrou 2006). Then, the soil organic matter was removed from the soil sample by addition of $15 \%$, and then $35 \%$ of a $\mathrm{H}_{2} \mathrm{O}_{2}$ solution (up to 1 week for the upper soil horizons, which have the highest organic matter content). During the whole procedure, $\mathrm{pH}$ was maintained above 3 using $0.5 \mathrm{M} \mathrm{NaOH}$ to prevent any clay destruction. In a last step, $0.5 \mathrm{~mL}$ of sodium hexametaphosphate $(1.6 \mathrm{mM})$ was added to deflocculate clay particles before analyses. Resulting suspensions were analysed using a Malvern laser Mastersizer 2000.

The mineralogical content of soil samples was determined on the powdered fraction $(>2 \mathrm{~mm}$ and no $\mathrm{HCl}$ treatment) using a Thermo Scientific ARL X'TRA powder diffractometer. Diffractograms were analysed using the MacDiff software (Petschick 2001). 


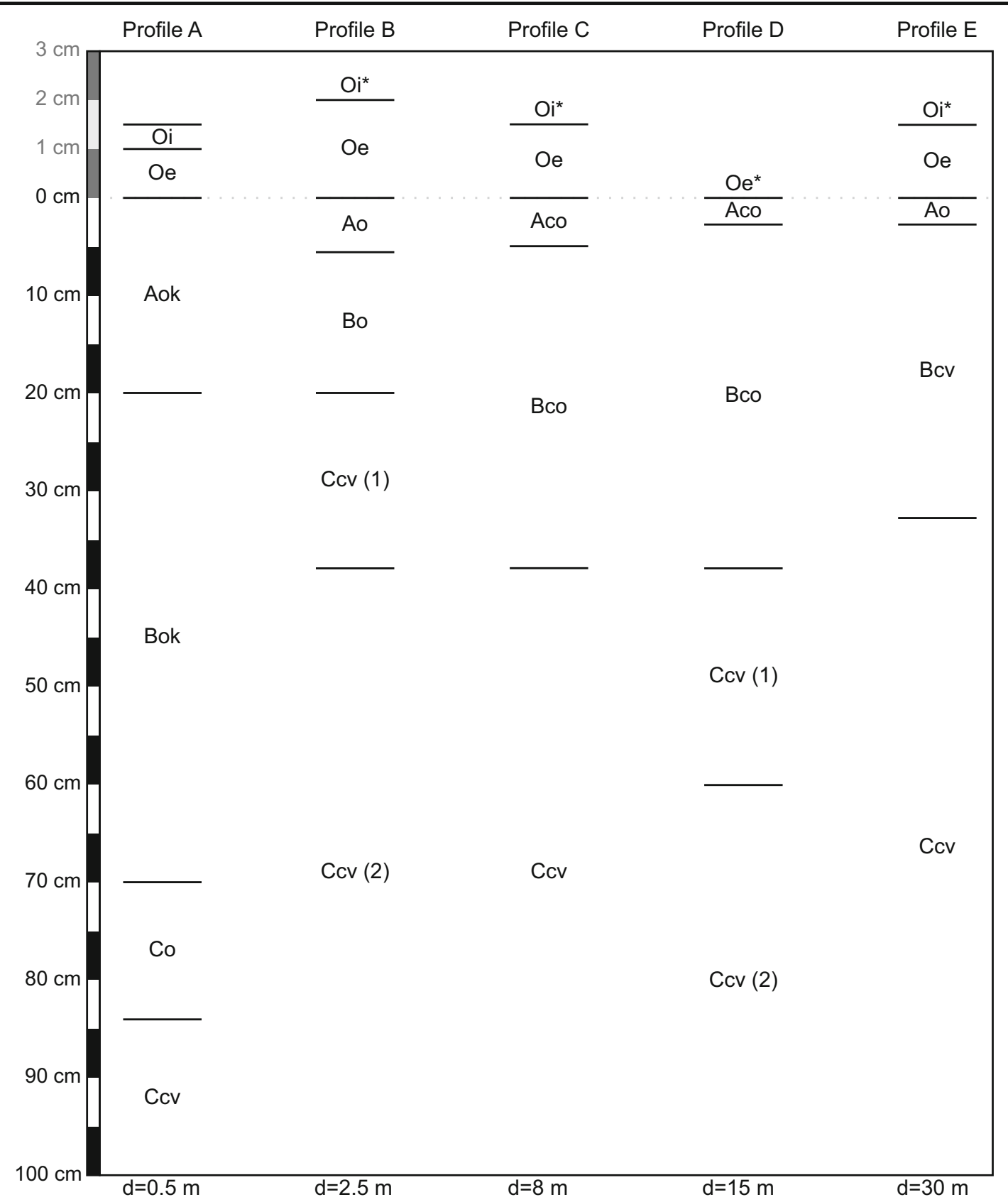

Fig. 1 Catena of soil profiles with horizon type (FAO 2006) at the five stations (a to e) along the $30 \mathrm{~m}$ long transect. "*” discontinuous layer

The $\mathrm{pH}_{\mathrm{H} 2 \mathrm{O}}$ of soil samples was determined using $10 \mathrm{~g}$ of $>2 \mathrm{~mm}$ sieved sample added to $20 \mathrm{~mL}$ of deionised water (Vogel 1994). The $\mathrm{pH}$ was determined after $16 \mathrm{~h}$ of shaking on a rotary table using a Metrohm $^{\mathrm{TM}} \mathrm{pH}$-meter.

Total carbon $\left(\mathrm{Corg}_{\mathrm{Tot}}\right)$ and nitrogen $\left(\mathrm{N}_{\mathrm{Tot}}\right)$ contents were measured using a Thermo Scientific CHNS
Elemental Analyser FlashEA 1112. Major total elemental contents, i.e. phosphorus, potassium, calcium, and magnesium ( $\mathrm{P}_{\mathrm{Tot}}, \mathrm{K}_{\mathrm{Tot}}, \mathrm{Ca}_{\mathrm{Tot}}$, and $\mathrm{Mg}_{\mathrm{Tot}}$, respectively), were determined on bulk soil samples using a mix of $12 \mathrm{~g}$ of sample powder $(n=120)$ and $3 \mathrm{~g}$ of Hoechst wax $\mathrm{C}$ micropowder for X-ray fluorescence analysis. Samples were pressed up to 10 tons to obtain tablets to be 
analysed. Analyses were performed using a Panalytical PW2400 X-ray fluorescence spectrometer. This method allows fast, accurate, and reproducible measurements for soil samples while avoiding the use of strong acid dissolution (Fitton 1997). XRF calibration is done with solid sample for which the chemical composition is entirely known. The chemical composition measured using the XRF has a lower limit of detection of $20 \mathrm{ppm}$ with a maximal error of $2 \%$.

Remains of soil sample triplicates were pooled ( $n=40)$ to measure exchangeable cation contents $\left(\mathrm{Ca}_{\mathrm{e}}, \mathrm{Mg}_{\mathrm{e}}, \mathrm{K}_{\mathrm{e}}\right)$. Ammonium acetate $1 \mathrm{M}$ was used for extraction and soil extracts were filtered at $0.2 \mu \mathrm{m}$. Concentrations of $\mathrm{Ca}^{2+}, \mathrm{Mg}^{2+}$, and $\mathrm{K}^{+}$were measured using a Perkin Elmer ICP-OES Optima 8300 (Pansu and Gautheyrou 2006).

\section{Statistical processing}

A one-way analysis of variance (ANOVA) and Tukey's HSD tests were used to compare means of each soil parameter measured (see below for calculations of $\mathrm{pH}$ means). These comparisons allow to find means that are significantly different from each other, in order to determine the limits of influence of the iroko tree (i) along the transect (horizontal pattern), and (ii) from the top to the maximum depth of the soil profile (samples $n=120$; vertical pattern). Linear spline interpolation maps were calculated using R's Akima package (Akima et al. 2009; R Development Core Team 2012). As pH is a logarithmic variable, an arithmetic mean cannot be applied. Consequently a geometric mean was used for each triplicate of $\mathrm{pH}$ values. Moreover, linear interpolation for $\mathrm{pH}$ cannot be used, so, instead, the geometric means previously calculated were transformed into concentrations of protons (i.e. $10^{-\mathrm{pH}}$ ) on which a spline interpolation was performed. Then, the newly obtained interpolated concentrations of proton are back-transformed to $\mathrm{pH}$ values (i.e. $-\log$ (concentration of protons)) to be plotted as a map for $\mathrm{pH}$ distribution. Average values of soil triplicate variables $\left(\mathrm{Ca}_{\mathrm{Tot}}, \mathrm{Mg}_{\mathrm{Tot}}\right.$, $\mathrm{K}_{\text {Tot }}, \mathrm{P}_{\text {Tot }}$, Corg $\mathrm{Cot}_{\text {Tot }}$, and $\mathrm{N}_{\text {Tot }}$ ) were calculated and merged to the dataset containing the exchangeable cation contents in order to perform Principal Component Analysis (PCA). PCA was calculated on $n=$ 12 variables and $n=40$ samples using R's FactorMineR package (Husson et al. 2014).

\section{Results}

Loamy texture predominated in the five soil profiles (Table 1). Proportions of the various minerals in the soil profile at station A are given in Fig. 2. Phyllosilicates, mainly kaolinite, and quartz were dominant. No illiteclays were observed. The $\mathrm{pH}, \mathrm{Corg}_{\text {Tot }}$ and nutrient distributions are presented in Figs. 3 and 4. ANOVA and post-ANOVA Tukey test results are given in Table 2. For reference, the individual data for the ten edaphic variables (pH, Ca $\mathrm{a}_{\text {Tot }}, \mathrm{Ca}_{\mathrm{e}}, \mathrm{Mg}_{\text {Tot }}, \mathrm{Mg}_{\mathrm{e}}, \mathrm{K}_{\text {Tot }}, \mathrm{K}_{\mathrm{e}}, \mathrm{P}_{\text {Tot }}$, Corg $_{\text {Tot }}$, and $\mathrm{N}_{\text {Tot }}$ ) are given in two supplementary tables (supplementary table 3, $n=120$; supplementary table 4; $n=40$ ). In order to prevent the questioning of the data measured around this only tree, supplementary $\mathrm{pH}$ data obtained during the exploration phase of the same area of Malentouen (east of Foumban, $5^{\circ} 43^{\prime} 0^{\prime \prime} \mathrm{N}, 10^{\circ} 55^{\prime} 0^{\prime \prime} \mathrm{E}$ ) are given in a supplementary table (table 5). They support the idea that while an iroko tree grows, soil $\mathrm{pH}$ becomes more and more alkaline.

The soil pH (Fig. 3a) showed significant differences only as a function of distance ( $p$-value $<0.001$ ), i.e. along the horizontal axis from the iroko tree. Under the iroko tree, $\mathrm{pH}$ averaged from 7.0 to 6.5 , while $\mathrm{pH}$ decreased with averages below 5.4 at $8-15 \mathrm{~m}$ from the tree.

There were significant differences between means for both Corg ${ }_{\text {Tot }}$ and $\mathrm{N}_{\text {Tot }}$ as a function of both distance ( $p$ values $<0.001)$ and depth ( $p$-values $<0.001$; Fig. $3 b$,c). The highest $\operatorname{Corg}_{\text {Tot }}$ mean is observed in soils at station A, decreasing towards station C. Whatever topsoil samples (down to $10 \mathrm{~cm}$ deep) values, for each station a decrease occurred as a regular sigmoid curve along depth without any clear threshold. Regarding $\mathrm{N}_{\text {Tot }}$, samples at station A displayed the highest mean. The general trend was an exponential decay-like curve with distance from the iroko tree. $\mathrm{N}_{\text {Tot }}$ vertical distribution was quite similar to that of Corg Tot $_{\text {although less regular }}$ than for the latter.

There was no difference in $\mathrm{P}_{\text {Tot }}$ (Fig. $3 \mathrm{~d}$ ) and $\mathrm{K}_{\text {Tot }}$ (Fig. $4 \mathrm{a})$ as a function of the distance from the tree $(p$ values $>0.4)$. However, there were significant differences for $\mathrm{P}_{\text {Tot }}$ and $\mathrm{K}_{\text {Tot }}$ regarding depth ( $p$-values $<0.001)$. The means of samples $>30 \mathrm{~cm}$ depth were different from the others. The $\mathrm{P}_{\mathrm{Tot}}$ vertical trends were regular sigmoid curves that decreased with depth. The $\mathrm{K}_{\text {Tot }}$ vertical trends were similar to those of $\mathrm{P}_{\text {Tot }}$ excepted that topsoil values displayed a less regular pattern with distance from the tree. 
Table 1 Percentages of sand, silt, and clay in the different horizons from the A to E stations and associated USDA textures (Schoeneberger et al. 2012)

\begin{tabular}{|c|c|c|c|c|}
\hline Profiles - Horizons & $\begin{array}{l}\text { Clays } \\
(<2 \mu \mathrm{m})\end{array}$ & $\begin{array}{l}\text { Silts } \\
(2-50 \mu \mathrm{m})\end{array}$ & $\begin{array}{l}\text { Sands } \\
(0.05-2 \mathrm{~mm})\end{array}$ & USDA textures \\
\hline A - Aok & 24.1 & 36.36 & 39.55 & Loam \\
\hline A - Bok & 25.68 & 42.19 & 32.13 & Loam \\
\hline $\mathrm{A}-\mathrm{Co}$ & 27 & 39.53 & 33.48 & Loam \\
\hline $\mathrm{A}-\mathrm{Ccv}$ & 24.68 & 35.11 & 40.21 & Loam \\
\hline B - Ao & 25.25 & 36.88 & 37.87 & Loam \\
\hline B - Bo & 23.55 & 37.26 & 39.19 & Loam \\
\hline B - Ccv (1) & 26.23 & 35.1 & 38.67 & Loam \\
\hline B - Ccv (2) & 22.79 & 31.02 & 46.19 & Loam \\
\hline C - Aco & 18.79 & 25.53 & 55.69 & Sandy loam \\
\hline $\mathrm{C}-\mathrm{Bco}$ & 26.99 & 26.16 & 46.85 & sandy clay loam \\
\hline $\mathrm{C}-\mathrm{Ccv}$ & 32.61 & 31.42 & 35.96 & clay loam \\
\hline D - Aco & 17.62 & 29.46 & 52.92 & Sandy loam \\
\hline D - Bco & 31.31 & 24.65 & 44.05 & clay loam \\
\hline D - Ccv (1) & 21.08 & 19.01 & 59.91 & sandy clay loam \\
\hline D - Ccv (2) & 37 & 32.43 & 30.56 & clay loam \\
\hline E - Aco & 16.13 & 25.94 & 57.92 & Sandy loam \\
\hline E - Bco & 32.67 & 28.4 & 38.92 & clay loam \\
\hline $\mathrm{E}-\mathrm{Ccv}$ & 33.09 & 42.98 & 23.93 & clay loam \\
\hline T1 - Aco & 21.29 & 31.8 & 46.92 & Loam \\
\hline T2 - Aco & 21.78 & 32.54 & 45.63 & Loam \\
\hline T3 - Aco & 21.94 & 33.03 & 45.04 & Loam \\
\hline
\end{tabular}

The $\mathrm{K}_{\mathrm{e}}$ (Fig. 4b) showed significant differences between means as a function of distance from the iroko tree ( $p$-value $<0.001)$. However, there was no clear trend. The highest mean was observed at station $\mathrm{B}$, which was different from more distant stations (C-E) that presented the lowest means.

$\mathrm{Ca}_{\text {Tot }}$ and $\mathrm{Mg}_{\text {Tot }}$ (Fig. 4c and e, respectively) showed significant differences as a function of distance ( $p$ values <0.001). The highest $\mathrm{Ca}_{\text {Tot }}$ and $\mathrm{Mg}_{\text {Tot }}$ means were observed at station A, decreasing to an interval between stations $\mathrm{C}$ and $\mathrm{D}$. This general trend was less regular for $\mathrm{Mg}_{\text {Tot. }}$. There was a slight difference in means for both $\mathrm{Ca}_{\mathrm{Tot}}$ and $\mathrm{Mg}_{\mathrm{Tot}}$ as a function of depth ( $p$-values $<0.1$ and $<0.01$, respectively), this being only visible between the most remote depths i.e. 5 and $100 \mathrm{~cm}$. Both $\mathrm{Ca}_{\mathrm{e}}$ and $\mathrm{Mg}_{\mathrm{e}}$ (Fig. 4d and f, respectively) presented significant differences between means as a function of distance $(p$-values <0.001). Stations A (and B when

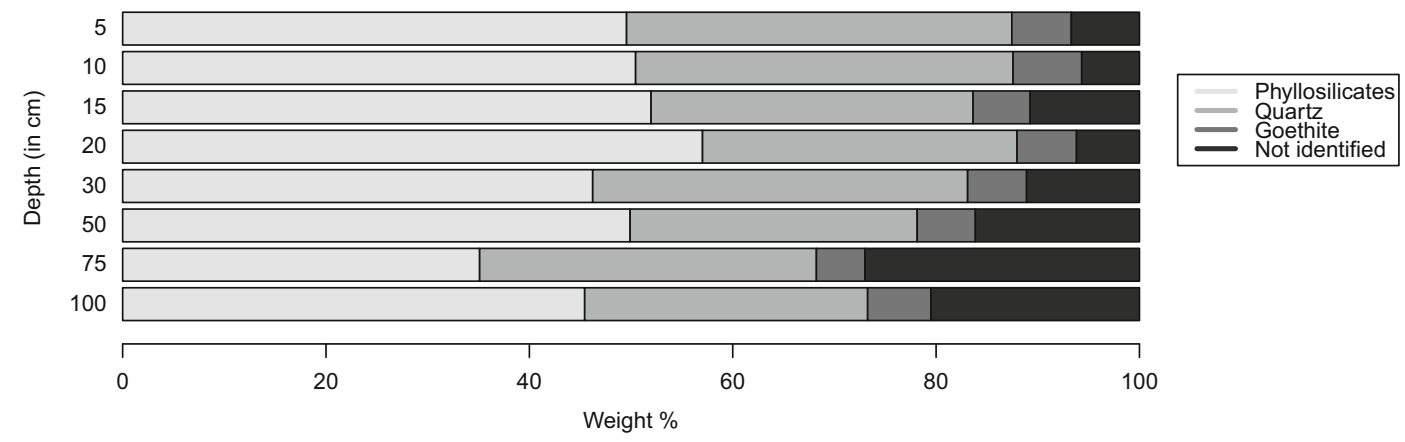

Fig. 2 Relative proportions of mineral phases from the soil profile at station A 


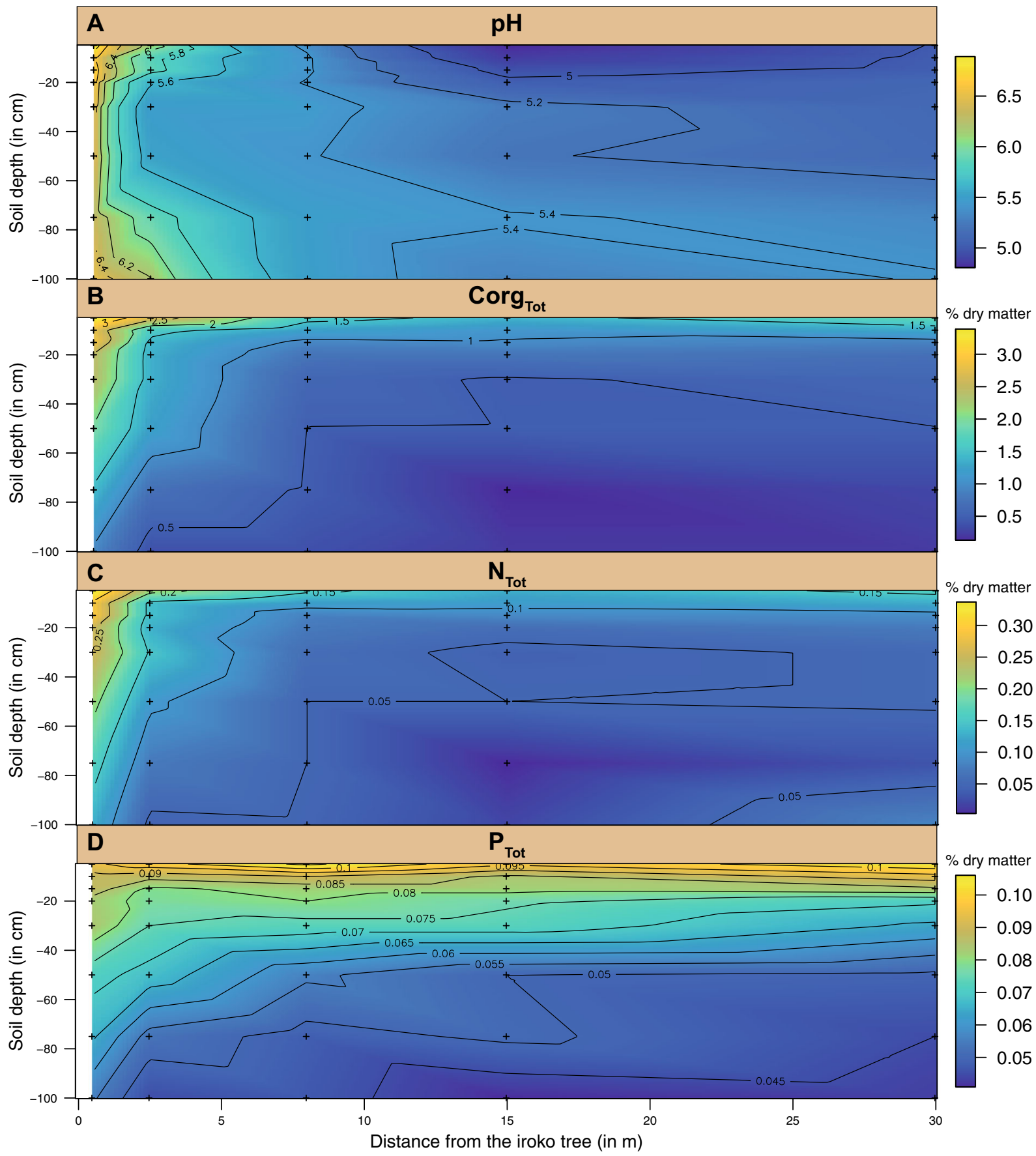

Fig. 3 Interpolated 2D maps using averages of triplicates $(n=120)$. a Map of soil $\mathrm{pH}$. b Map of soil total organic carbon content $\left(\mathrm{Corg}_{\mathrm{Tot}}\right.$ in \% dry matter). c Map of soil total nitrogen content $\left(\mathrm{N}_{\mathrm{Tot}}\right.$ - in \% dry matter). $\mathbf{d}$ Map of soil total phosphorus content $\left(\mathrm{P}_{\mathrm{Tot}}-\right.$ in $\%$ dry matter $)$

considering $\mathrm{Ca}_{\mathrm{e}}$ ) had the highest means, then there was a decrease toward stations further away from the tree.

The two first principal components (PC1 and PC2) accounted for $79 \%$ of the total variance, using all the parameters analysed in this study (Fig. 5a). The first principal component (PC1) was mainly influenced by $\mathrm{Mg}_{\text {Tot }}, \mathrm{Ca}_{\text {Tot }}, \mathrm{N}_{\text {Tot }}$, and $\operatorname{Corg}_{\text {Tot }}$ (sorted by increasing weight on PC1). On the other hand, $\mathrm{K}_{\text {Tot }}$, depth, and $\mathrm{P}_{\text {Tot }}$ 


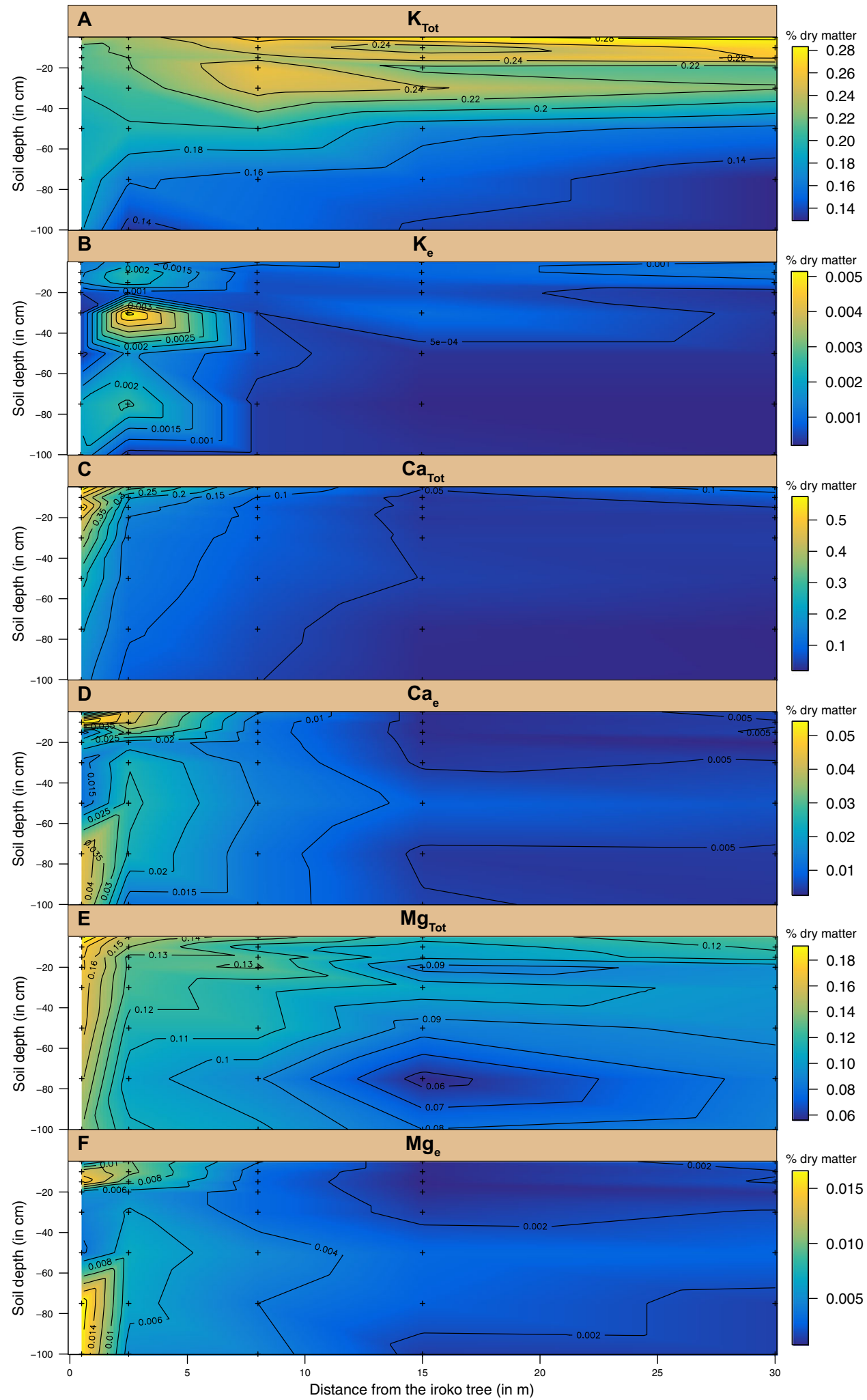


Fig. 4 a Interpolated 2D maps using averages of triplicates ( $n=$ 120) for soil total potassium content $\left(\mathrm{K}_{\mathrm{Tot}}-\right.$ in $\%$ dry matter). b Interpolated map $(n=40)$ for the soil exchangeable potassium content $\left(\mathrm{K}_{\mathrm{e}}\right.$ - in \% dry matter). c Interpolated map using the average of triplicates $(n=120)$ for the soil total calcium content $\left(\mathrm{Ca}_{\mathrm{Tot}}\right.$ - in $\%$ dry matter). d Interpolated map $(n=40)$ for the soil exchangeable calcium content $\left(\mathrm{Ca}_{\mathrm{e}}-\right.$ in $\%$ dry matter $)$. e Interpolated map using the average of triplicates $(n=120)$ for the soil total magnesium content $\left(\mathrm{Mg}_{\text {Tot }}\right.$ - in \% dry matter). f Interpolated map $(n=40)$ for the soil exchangeable magnesium content $\left(\mathrm{Mg}_{\mathrm{e}}\right.$ - in \% dry matter)

(sorted by increasing weight) contributed to the second principal component (PC2). The PCA showed that $\mathrm{K}_{\mathrm{Tot}}$ and $\mathrm{P}_{\text {Tot }}$ (Group 1) were negatively correlated with depth, while $\mathrm{pH}, \mathrm{Mg}_{\mathrm{e}}$, and $\mathrm{Ca}_{\mathrm{e}}$ (Group 2) were negatively correlated with distance. Finally, a third group of variables containing $\mathrm{Ca}_{\text {Tot }}, \mathrm{Mg}_{\text {Tot }}, \mathrm{N}_{\text {Tot }}$, and Corg $\mathrm{Cot}_{\text {Tot }}$ constituted Group 3, which mainly contributed to PC1. All these variables from Group 3 were relatively wellcorrelated to each other and their projection on the PC1xPC2 plane was in-between Groups 1 and 2. However, $\mathrm{K}_{\mathrm{e}}$ did not significantly contribute to either the first or the second principal components. As the depth and distance variable projection in the PC1xPC2 space are close to perpendicular, we can visualize how the other variables behave in this PCA space, relatively to the depth-distance Euclidian space. This will provide a rough visual estimate of the relative quantification of the variable dependence to both distance and depth in the PC1xPC2 space (Fig. 5b,c). Distance accounted for $99 \%$ of the $\mathrm{pH}$ and $\mathrm{Ca}_{\mathrm{e}}$ variability, while it was $95 \%$ for $\mathrm{Mg}_{\mathrm{e}} \cdot \mathrm{K}_{\mathrm{e}}$ was not taken into account as its contribution was too low. $\mathrm{Ca}_{\mathrm{Tot}}, \mathrm{Mg}_{\text {Tot }}, \mathrm{N}_{\text {Tot }}$, and $\mathrm{Corg}_{\text {Tot }}$ variability was accounted for in a range of 74-66-62-56\% by the distance in the depth-distance Euclidian space. $\mathrm{P}_{\text {Tot }}$ and $\mathrm{K}_{\text {Tot }}$ variability accounted for less than $20 \%$ by the distance, while depth accounted for 95 and $89 \%$ in $\mathrm{K}_{\mathrm{Tot}}$ and $\mathrm{P}_{\text {Tot }}$ variability, respectively. The other variables depended on depth in a range of $51-14 \%$.

\section{Discussion}

Ten edaphic variables were assessed in this study in order to highlight the relative weight of the distance from an iroko tree vs the soil depth on soil nutrient distribution in an oxalogenic-oxalotrophic ecosystem. The distribution of each element is discussed separately, by focusing on its relationship with the distance (horizontal pattern) and the depth (vertical pattern). The spatial distribution of potentially acting processes that influence the dynamics of soil nutrients is also described. Finally, the specific context of the OCP is discussed, in order to understand its impact on the modification of pedogenic processes.

Table 2 ANOVA and results from the post-ANOVA Tukey test given in function of distance and depth

\begin{tabular}{|c|c|c|c|c|c|c|c|c|c|c|c|c|c|c|c|c|}
\hline \multicolumn{7}{|c|}{ Distance (m) } & \multicolumn{10}{|c|}{ Depth $(\mathrm{cm})$} \\
\hline Variable & p-value & 0.5 & 2.5 & 8 & 15 & 30 & Variable & p-value & 5 & 10 & 15 & 20 & 30 & 50 & 75 & 100 \\
\hline $\mathrm{pH}$ & $<0.001$ & $\mathrm{a}$ & $\mathrm{b}$ & $\mathrm{c}$ & $\mathrm{d}$ & $\mathrm{d}$ & $\mathrm{pH}$ & 0.9734 & - & - & - & - & - & - & - & - \\
\hline Corg $_{\text {Tot }}$ & $<0.001$ & $\mathrm{a}$ & $\mathrm{b}$ & $\mathrm{c}$ & $\mathrm{c}$ & $\mathrm{c}$ & Corg $_{\text {Tot }}$ & $<0.001$ & $\mathrm{a}$ & $a b$ & $a b c$ & bcd & bcd & bcd & $\mathrm{cd}$ & $\mathrm{d}$ \\
\hline $\mathrm{N}_{\text {Tot }}$ & $<0.001$ & $\mathrm{a}$ & $\mathrm{b}$ & $\mathrm{bc}$ & $\mathrm{c}$ & $\mathrm{bc}$ & $\mathrm{N}_{\text {Tot }}$ & $<0.001$ & $\mathrm{a}$ & $\mathrm{ab}$ & $a b c$ & $a b c$ & $a b c$ & $\mathrm{bc}$ & $\mathrm{c}$ & $\mathrm{c}$ \\
\hline $\mathrm{P}_{\mathrm{Tot}}$ & 0.4087 & - & - & - & - & - & $\mathrm{P}_{\mathrm{Tot}}$ & $<0.001$ & $\mathrm{a}$ & $\mathrm{b}$ & $\mathrm{bc}$ & $\mathrm{cd}$ & $\mathrm{d}$ & $\mathrm{e}$ & ef & $\mathrm{f}$ \\
\hline $\mathrm{K}_{\mathrm{Tot}}$ & 0.6450 & - & - & - & - & - & $\mathrm{K}_{\mathrm{Tot}}$ & $<0.001$ & $\mathrm{a}$ & $a b$ & $a b$ & $\mathrm{~b}$ & $\mathrm{~b}$ & $\mathrm{c}$ & $\mathrm{cd}$ & $\mathrm{d}$ \\
\hline $\mathrm{K}_{\mathrm{e}}$ & $<0.001$ & $\mathrm{ab}$ & $\mathrm{a}$ & $\mathrm{b}$ & $\mathrm{b}$ & $\mathrm{b}$ & $\mathrm{K}_{\mathrm{e}}$ & 0.6873 & - & - & - & - & - & - & - & - \\
\hline $\mathrm{Ca}_{\mathrm{Tot}}$ & $<0.001$ & $\mathrm{a}$ & $\mathrm{b}$ & $\mathrm{c}$ & $\mathrm{c}$ & $\mathrm{c}$ & $\mathrm{Ca}_{\mathrm{Tot}}$ & $<0.1$ & $\mathrm{a}$ & $\mathrm{ab}$ & $\mathrm{ab}$ & $\mathrm{ab}$ & $\mathrm{ab}$ & $a b$ & $\mathrm{ab}$ & $\mathrm{b}$ \\
\hline $\mathrm{Ca}_{\mathrm{e}}$ & $<0.001$ & $\mathrm{a}$ & $\mathrm{a}$ & $\mathrm{b}$ & $\mathrm{b}$ & $\mathrm{b}$ & $\mathrm{Ca}_{\mathrm{e}}$ & 0.9232 & - & - & - & - & - & - & - & - \\
\hline $\mathrm{Mg}_{\mathrm{Tot}}$ & $<0.001$ & $\mathrm{a}$ & $\mathrm{b}$ & $\mathrm{bc}$ & $\mathrm{d}$ & $\mathrm{cd}$ & $\mathrm{Mg}_{\mathrm{Tot}}$ & $<0.01$ & $\mathrm{a}$ & $\mathrm{ab}$ & $\mathrm{ab}$ & $\mathrm{ab}$ & $\mathrm{ab}$ & $a b$ & $\mathrm{~b}$ & $\mathrm{~b}$ \\
\hline $\mathrm{Mg}_{\mathrm{e}}$ & $<0.001$ & $\mathrm{a}$ & $\mathrm{ab}$ & $\mathrm{bc}$ & $\mathrm{c}$ & $\mathrm{c}$ & $\mathrm{Mg}_{\mathrm{e}}$ & 0.9180 & - & - & - & - & - & - & - & - \\
\hline
\end{tabular}

Data processing for $\mathrm{pH}, \mathrm{Ca}_{\mathrm{Tot}}, \mathrm{Mg}_{\mathrm{Tot}}, \mathrm{K}_{\mathrm{Tot}}, \mathrm{P}_{\mathrm{Tot}}, \mathrm{Corg}_{\mathrm{Tot}}$, and $\mathrm{N}_{\mathrm{Tot}}$ is performed with $n=120$ samples, whereas for Ca, $\mathrm{K}_{\mathrm{e}}$, and $\mathrm{Mg}_{\mathrm{e}}, n=40$ samples have been taken. Means displayed with the same letter are not significantly different 
A

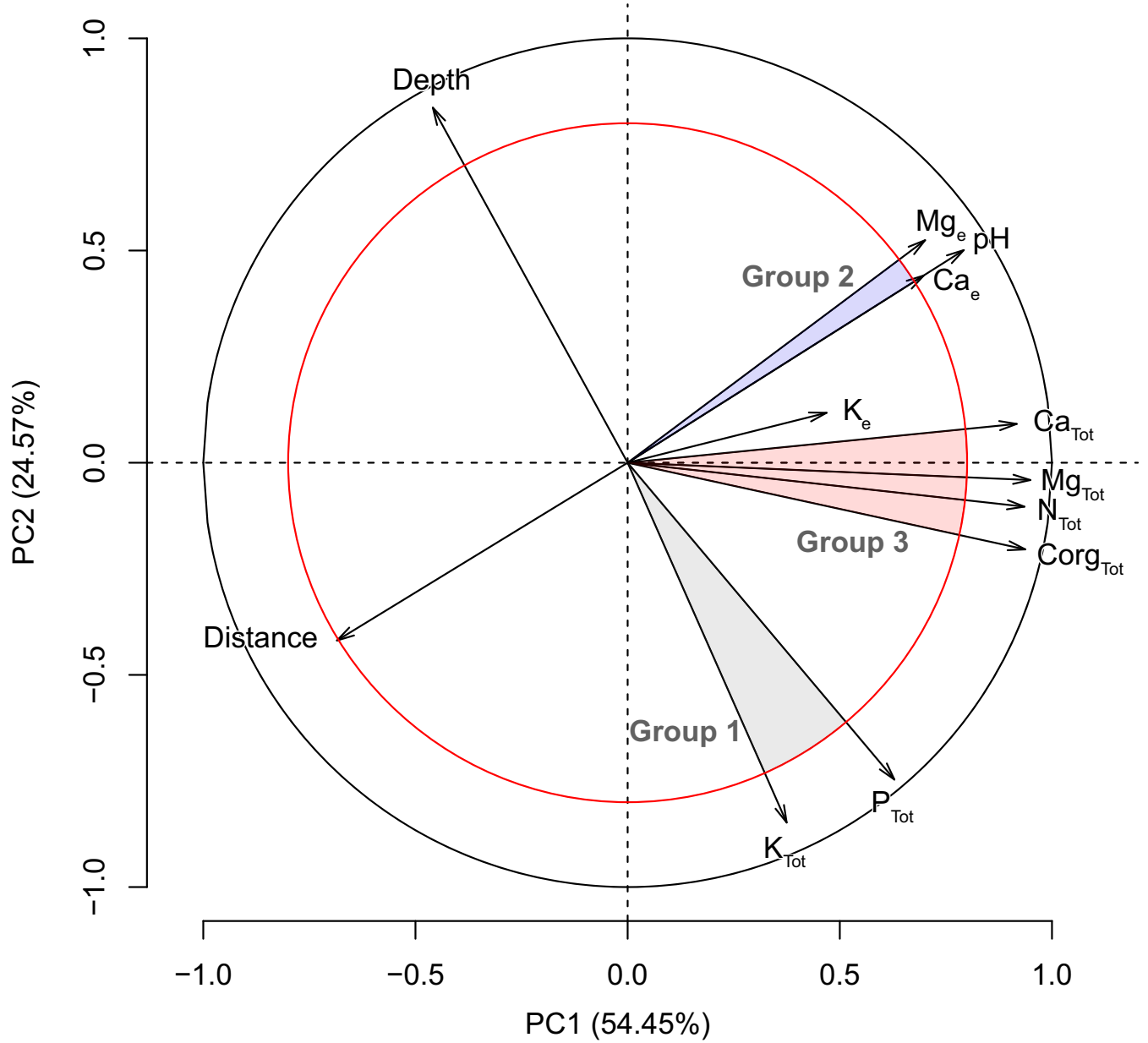

B

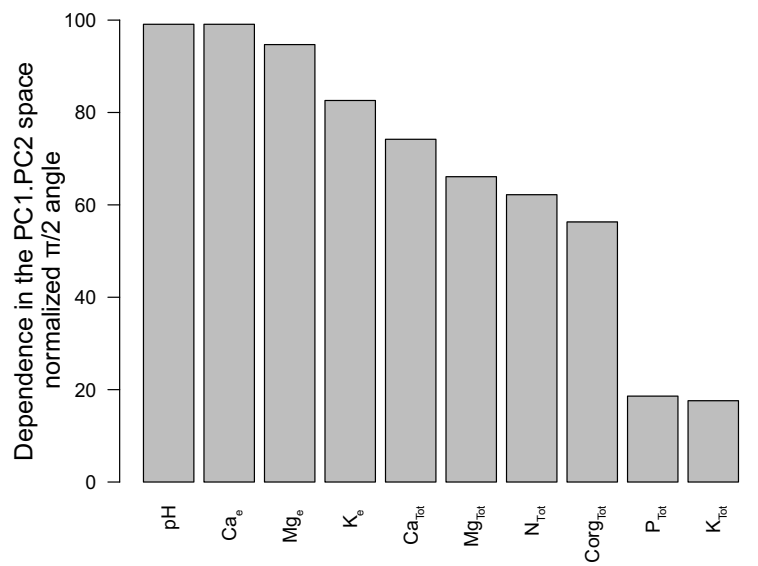

Fig. 5 Principal component analysis plots. a Correlation circle of the 12 variables, 3 groups of edaphic indexes, and the first and second principal components $(79 \%$ of the total variance explained). Inner (red) and outer (black) circles represent correlation coefficients equal to 0.8 and 1 , respectively, between variables and principal components. b Relationships between the 10 edaphic
C

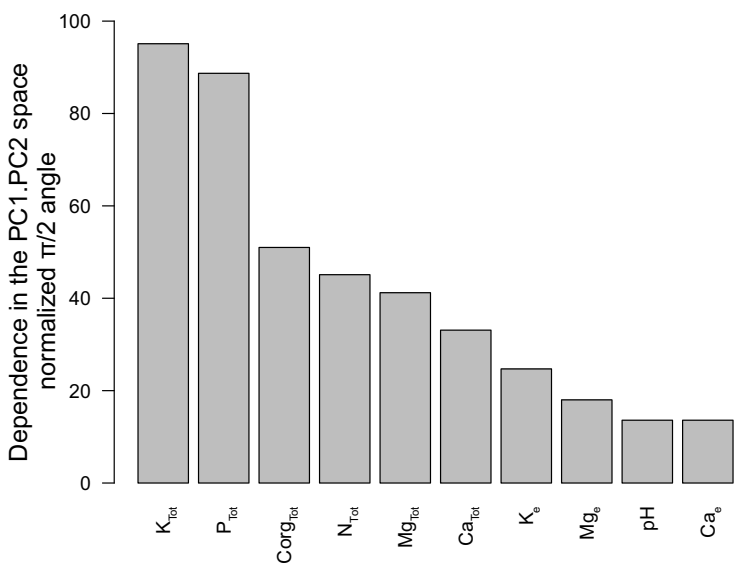

variables $v s$ the distance. This relationship is expressed as a normalized $\pi / 2$ angle in the PC1xPC2 plane (79\% of the total variance explained). c Relationships between the 10 edaphic variables $v s$ the depth. This relationship is expressed as a normalized $\pi / 2$ angle in the PC1xPC2 plane (79\% of the total variance explained) 
Horizontal pattern of soil parameters: the "influence" of distance

The exchangeable fractions of $\mathrm{Ca}_{\mathrm{e}}$ and $\mathrm{Mg}_{\mathrm{e}}$ strongly depend on the distance from the tree, and their distributions are closely linked to $\mathrm{pH}$ (Fig. 5). Interestingly, these exchangeable fractions do not group with their related counterparts $\mathrm{Ca}_{\mathrm{Tot}}$ and $\mathrm{Mg}_{\mathrm{Tot}}$. This suggests a decoupling of the exchangeable fraction from the total fraction. In the study area, it is expected that organic matter $(\mathrm{OM})$ provides the largest part of $\mathrm{Ca}_{\mathrm{Tot}}$ and $\mathrm{Mg}_{\mathrm{Tot}}$ to the soil through litterfall (Vitousek 1984; Vitousek and Sanford 1986; Jobbágy and Jackson 2001). This is supported by the fact that both $\mathrm{Ca}_{\mathrm{Tot}}$ and $\mathrm{Mg}_{\mathrm{Tot}}$ belong in the PCA to Group 3, which also contains $\operatorname{Corg}_{\text {Tot }}$. However, the exchangeable fractions of $\mathrm{Ca}_{\mathrm{e}}$ and $\mathrm{Mg}_{\mathrm{e}}$, display different distributions even if they represent small fractions compared to the total amount. This suggests divergent chemical dynamics along the $30 \mathrm{~m}$ long transect from the iroko tree. The $\mathrm{pH}$ is the most likely driving force for the exchangeable fractions of $\mathrm{Ca}$ and $\mathrm{Mg}$. An increase in $\mathrm{pH}$ leads to an increase in $\mathrm{pH}-$ dependent charge (variable charges), allowing greater retention of positive ions (Evans 1989). It is a wellknown phenomenon for metal adsorption on mineral surfaces (including oxides). The alkalinization and the concomitant decrease of $\left[\mathrm{H}^{+}\right]$in the soil/water solution allow also for a greater amount of $\mathrm{Ca}^{2+}$ and $\mathrm{Mg}^{2+}$ ions to be bond to the humus-clay complex instead of $\mathrm{Al}^{3+}$ and $\mathrm{Fe}^{2+}$. This explains why $\mathrm{Ca}$ is often mentioned in the literature as the dominant exchangeable cation at $\mathrm{pH} 6$ to 7 (Oertli 2008). Finally, this grouping of $\mathrm{pH}, \mathrm{Ca}_{\mathrm{e}}$, and $\mathrm{Mg}_{\mathrm{e}}$ variables is not unexpected since the $\mathrm{pH}$ in the soil studied is only slightly over 6.5. Indeed, higher $\mathrm{pH}$ should cause a dramatic drop of the $\mathrm{Mg}_{\mathrm{e}}$ (Chan et al. 1979). At higher $\mathrm{pH}, \mathrm{Mg}_{\mathrm{e}}$ and $\mathrm{Ca}_{\mathrm{e}}$ are expected to react divergently.

The effect of distance on $\mathrm{K}_{\mathrm{e}}$ is also detected using ANOVA: both stations $\mathrm{B}$, and in a lesser extent $\mathrm{A}$, have greater amounts of $\mathrm{K}_{\mathrm{e}}$ than the more distant stations. Such a lateral distribution for $\mathrm{K}_{\mathrm{e}}$ is uncommon, since a vertical trend is more likely to be observed (Jobbágy and Jackson 2001). Similarly to $\mathrm{Ca}_{\mathrm{e}}$ and $\mathrm{Mg}_{\mathrm{e}}$, variations of soil properties, such as the $\mathrm{pH}$ conditions resulting from the oxalogenic-oxaltrophic ecosystem, are likely to influence the distribution of $\mathrm{K}_{\mathrm{e}}$. Variation of $\mathrm{pH}$ dependent charge may be a hypothesis to be tested in the future for such a trend. Considering the most abundant clay in the studied soil, i.e. kaolinite, its zero point charge is usually $<4$ (Appel et al. 2003). The drastic variation of $\mathrm{pH}$ (i.e. from 5 to 6 ) between stations $\mathrm{B}$ and $\mathrm{C}$ (Fig. 3a) may therefore affect $\mathrm{K}_{\mathrm{e}}$ by variation of the electric properties of clays in function of $\mathrm{pH}$.

The vertical pattern of soil parameters: the "influence" of depth

Depth influences $\mathrm{K}_{\mathrm{Tot}}$ and $\mathrm{P}_{\text {Tot }}$ concentrations, two major nutrients for plants. Primary K- and P-bearing minerals were not detected in the mineralogical analyses of the highly weathered Ferralsols. Therefore, we assume that these two nutrients are provided by the turnover of (OM).

To start with $\mathrm{K}$, a parallel discussion of $\mathrm{K}_{\mathrm{Tot}}$ and $\mathrm{K}_{\mathrm{e}}$ is used to highlight the trend with depth in the biogeochemistry of K. First of all, stations D to E present an interesting pattern for $\mathrm{K}_{\mathrm{Tot}}$ and $\mathrm{K}_{\mathrm{e}}$, despite the fact that no difference was detected with other stations by using ANOVA. A decrease in $\mathrm{K}_{\text {Tot }}$ takes place from the topsoil down to the 20-30 cm depth interval (Fig. 4a). At $30 \mathrm{~cm}$ depth, there are slightly higher $\mathrm{K}_{\mathrm{Tot}}$ amounts than just above (at $20 \mathrm{~cm}$ depth), and then the $\mathrm{K}_{\text {tot }}$ decreases to $100 \mathrm{~cm}$. Coffee plants have a zone of root uptake mostly developed within the upper $30 \mathrm{~cm}$ of the soil (Gehrke 1962). As a consequence, the observed pattern can result from a balance between the litterfall input and the preferential root uptake by Coffee plants in this depth interval. This pattern is similar to the one observed in plant cycling, as described e.g. by Jobbágy and Jackson (2001).

The trend observed at stations D to E is not clearly visible in stations near the iroko tree. Stations $\mathrm{A}$ and $\mathrm{B}$ present a deepening of isolines for both $\mathrm{K}_{\text {Tot }}$ and $\mathrm{P}_{\text {Tot }}$ concentrations, which need further work to be more thoroughly understood. Another question that is still open for investigation is, in which fractions is the $\mathrm{K}$ contained in the two following distinct settings: i) the stations under the direct influence of the OCP (stations $\mathrm{A}$ and $\mathrm{B}$ ) and ii) the stations at remote distance from the tree (stations $\mathrm{C}$ to $\mathrm{E}$ )? Various factors can drive $\mathrm{K}$ distribution: i) OM inputs (quality or/and quantity), ii) variations in the dynamics of OM decay related to the $\mathrm{pH}$ increase linked to the OCP (Zech et al. 1997), iii) changes in the balance between the various soil $\mathrm{K}$ fractions (i.e. solution - exchangeable - fixed or non-exchangeable), as it is expected for $\mathrm{K}_{\mathrm{e}}$ (Acquaye 1973; Sparks 2000). This latter factor being under the influence of clay mineralogy, a small fraction (e.g. only 
$2 \%$ of 2:1 clay minerals in kaolinitic dominated Ferralsol-Poss et al. 1991) could significantly influence $\mathrm{K}$ distribution through retrogradation processes (Boyer 1973; Schneider et al. 2013). Consequently, further works should include a thorough clay study to understand their implication in $\mathrm{K}$ biogeochemistry in these soils. Additionally, to be even more exhaustive, $\mathrm{K}$ sources from the hydrosphere should also be included in order to fully understand the $\mathrm{K}$ cycle in such an ecosystem.

Similarly, $\mathrm{P}_{\text {Tot }}$ is either i) part of the $\mathrm{OM}$ fraction mostly fed by litterfall, ii) bound onto mineral surfaces (e.g. possibly kaolinite, goethite, and calcite; Fontes and Weed 1996; Frossard et al. 1995), and/or iii) present as inclusions co-precipitated with $\mathrm{Fe}$ - and Aloxyhydroxides (Fontes and Weed 1996; Miller et al. 2001). PCA (Fig. 5) shows that $P_{\text {Tot }}$ does not correlate

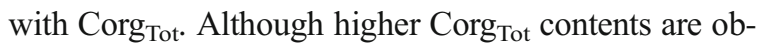
served in the upper $15 \mathrm{~cm}$, a Tukey test shows that $\mathrm{P}_{\text {Tot }}$ displays a similar threshold to $\operatorname{Corg}_{\text {Tot }}$ but at $30 \mathrm{~cm}$ depth only (Fig. 3d). This is the depth at which Coffee root uptake is assumed to create a depletion for $\mathrm{K}_{\mathrm{Tot}}$, especially at stations D and E. Further works are needed to fully understand $\mathrm{P}$ behavior in such a complex ecosystem. Because information is scarce in this $\mathrm{P}$ snapshot, future investigations on this fundamental subject of P cycling in tropical ecosystem should not overlook the impact of macrofauna (mainly termites) on transfers and dynamics (Chapuis-Lardy et al. 2011).

To summarize, there are different patterns for $\mathrm{K}_{\mathrm{Tot}}$ and $\mathrm{P}_{\text {Tot }}$ vertical trends observed at remote stations (stations $\mathrm{C}$ to $\mathrm{E}$ ) compared to stations under the influence of the iroko tree (stations $\mathrm{A}$ and $\mathrm{B}$ ). At remote stations the trend results from a balance between litter accumulations, responsible for nutrient supply, and root plant uptake (probably mostly coffee plants). Understanding the exact factors that drive $\mathrm{K}_{\text {Tot }}$ and $\mathrm{P}_{\text {Tot }}$ distributions at stations near the tree will need a more thorough study. Consequently, some aspects should be considered in the future: i) differences in the K plant uptake are anticipated due to antagonisms with other cations, such as Mg and Ca (Fageria 2001; Pathak and Kalra 1971); ii) $\mathrm{P}$ can bind either to $\mathrm{Fe}$ and $\mathrm{Al}$ in acidic conditions or to $\mathrm{Ca}$ under alkaline conditions (Ahmed et al. 2008; Hinsinger 2001). iii) Additionally, investigations on the interaction of $\mathrm{P}$ with organic complexes and acids could complete the picture. $\mathrm{P}$ availability for plants is strongly dependent on soil $\mathrm{pH}$. At the $\mathrm{pH}$ values measured, $\mathrm{P}$ availability should be higher near the iroko tree than away from it, i.e. high to medium versus low to medium i.e. in conventional $\mathrm{pH}$ ranges of 6.5 to 7 and $<5.4$, respectively. Consequently an indepth study of soil $\mathrm{pH}$ variations versus P-mineral binding would be a great asset to assess the benefits or drawbacks of the presence of an OCP ecosystem in agroforestry systems. As the lowest and highest $\mathrm{pH}$ measured in the present study were not the most extremes ever observed in an OCP ecosystem (unpublished data from other Cameroon field trips: from 4.3 up to 10.3), major issues for $\mathrm{P}$ availability are expected. As a result, $P$ accessibility for the plant and subsequent $P$ distribution in soil along a similar transect should be cautiously assessed by taking into account: i) variations at small scale of soil physicochemical parameters, such as $\mathrm{pH}$; ii) identify soil $\mathrm{K}$ - and $\mathrm{P}$ - bonded to $\mathrm{Mg}$, $\mathrm{Ca}, \mathrm{Fe}$, and/or $\mathrm{Al}$ bearing compounds; $\mathrm{K}$ and $\mathrm{P}$ content in Coffee plants should be investigated to assess the full plantsoil continuum.

Concomitant "influence" of depth and distance

The Group 3 variables $\left(\mathrm{Mg}_{\mathrm{Tot}}, \mathrm{Ca}_{\mathrm{Tot}}, \mathrm{N}_{\mathrm{Tot}}\right.$, and $\left.\mathrm{Corg}_{\mathrm{Tot}}\right)$, are correlated neither to the distance nor to the depth. No Ca-bearing mineral phases were detected despite the fact that Ca-carbonate was expected (Braissant et al. 2004; Carozzi 1967). So, two main Ca compartments can account for $\mathrm{Ca}_{\mathrm{Tot}}$ : an exchangeable pool representing only a small fraction, and the $\mathrm{Ca}$ present in OM, which represents the most important fraction of $\mathrm{Ca}_{\mathrm{Tot}}$. Additional $\mathrm{Ca}$ forms are expected, as mentioned for instance with $\mathrm{P}$ binding where alkaline conditions prevail. The strong relationship between $\mathrm{Corg}_{\mathrm{Tot}}$ and $\mathrm{Ca}_{\mathrm{Tot}}$, but also with $\mathrm{Mg}_{\mathrm{Tot}}$ (with $r^{2}=0.85$ and $r^{2}=$ 0.81 respectively; $n=40$ ), is well illustrated in the PC1xPC2 plane (Fig. 5). This supports the interpretation that $\mathrm{Ca}$ is mainly provided by $\mathrm{OM}$.

A similar link between $\mathrm{OM}$ and $\mathrm{Mg}$ is observed, although a smaller $\mathrm{Mg}$ content in the plant is expected (Raven et al. 2000). This highlights the fact that nutrient dynamics associated with the $\mathrm{OM}$ recycling characterizes these soils highly depleted in alkaline cations, and whatever the affinities of plants for a given element.

With $r^{2}=0.91(n=120), \mathrm{N}_{\text {Tot }}$ and $\operatorname{Corg}_{\text {Tot }}$ are well correlated, in agreement with the non-lithogenic nature of nitrogen. This also highlights the critical role of $\mathrm{OM}$ in soil $\mathrm{N}$ supply. Consequently, $\mathrm{OM}$ inputs directly influence $\mathrm{N}_{\text {Tot }}$ distribution, which is dependent on both 
depth and distance in this study. Only a depth trend is visible for the farthest stations, i.e. D and $\mathrm{E}$. This points to the importance of litterfall (whatever its origin) over the area. On the other hand, the high concentrations observed close to the iroko tree (even at great depth) raise questions about the source of N. Several explanations include i) slower OM decay and recycling, ii) more significant organic matter inputs to the soil, or iii) influence of the $\mathrm{pH}$ on microbial processes affecting the $\mathrm{N}$ turnover. Among those, slower OM dynamics appear unlikely as the $\mathrm{pH}$ increases (Balesdent et al. 2000; Van Bergen et al. 1998) and thus should enhance bacterial activity closer to the iroko tree (see the next section). On the other hand, higher OM inputs are expected close to a great deciduous tree, such as an iroko tree, than around smaller coffee shrubs. In addition, the nature of these inputs are different regarding locations (close or far away from the tree). Important bark desquamations were observed next to the iroko trunk. This supply can play a role in $\mathrm{N}$ distribution, even if they are more recalcitrant to decay, with a lower $\mathrm{N}$ content than dead leaves. Moreover, specific edaphic conditions, related to the $\mathrm{pH}$ increase close to the tree, cannot be excluded, as the $\mathrm{N}$ soil cycle and its different pathways are $\mathrm{pH}$ dependant (e.g. Čuhel et al. 2010).

To sum up, the respective influence of distance and depth upon the different variables measured in this study, as well as the relationships between $\mathrm{pH}, \mathrm{Mg}_{\mathrm{Tot}}$, $\mathrm{Ca}_{\text {Tot }}$, (and maybe $\mathrm{N}_{\mathrm{Tot}}$ ) deserve further investigation, particularly their projections in the PC1xPC2 plane. $\mathrm{Mg}_{\mathrm{e}}$ and $\mathrm{Ca}_{\mathrm{e}}$ are clearly related to both the $\mathrm{pH}$ and the distance to the iroko tree. To some extent, $\mathrm{Mg}_{\mathrm{e}}$ and $\mathrm{Ca}_{\mathrm{e}}$ also influence their total counterparts $\left(\mathrm{Mg}_{\mathrm{Tot}}\right.$ and $\left.\mathrm{Ca}_{\mathrm{Tot}}\right)$.

The central role of the oxalogenic tree and its associated ecosystem

So far, the concomitant roles of $\mathrm{pH}$ and soil organic matter (SOM; measured as $\mathrm{Corg}_{\mathrm{Tot}}$ ) as drivers of the nutrient distribution has emerged. These two variables are intrinsically dependent on the presence of an iroko tree that polarizes the $30 \mathrm{~m}$ long transect described in this study.

This tree species has been studied in many different sites (present study as well as Braissant et al. 2004; Cailleau 2005; Martin et al. 2012, and other unpublished results). Considering the importance of both $\mathrm{pH}$ and $\mathrm{Corg}_{\mathrm{Tot}}$ on nutrient distribution, the presence of an iroko tree and its associated OCP is seen as the corner stone that controls the local ecosystem.

In the study area, acidic soil conditions prevail (average $\mathrm{pH}=5.1$ at station $\mathrm{D}$ and $\mathrm{E} ; n=48$ ) in the absence of an efficient oxalogenic tree and the concomitant oxalotrophy at close vicinity. The $\mathrm{pH}$ reaches up to 7.4 (among $n=120$ ), i.e. a value slightly above neutrality, when an OCP is effective. Along the $30 \mathrm{~m}$ long transect, the $\mathrm{pH}$ shows only one clear trend, expressed along the distance from the oxalogenic tree, and this trend is observed whatever the depth considered. Consequently, the tree, through the oxalogenic-oxalotrophic ecosystem, drives the soil $\mathrm{pH}$, creating a gradient, which in turn, controls both $\mathrm{Ca}_{\mathrm{e}}$ and $\mathrm{Mg}_{\mathrm{e}}$ fractions. Their respective total fractions also exhibit this gradient along the transect. $\mathrm{Ca}_{\mathrm{Tot}}$ and $\mathrm{Mg}_{\mathrm{Tot}}$ concentrations close to the tree were expected to be due to carbonate accumulations below and near the trees as in previous studies (e.g. Cailleau et al. 2004, 2011). Despite the rather low pH observed at this study site, as well as the absence of significant carbonate accumulation near the trunk, $\mathrm{Ca}_{\mathrm{Tot}}$ and $\mathrm{Mg}_{\mathrm{Tot}}$ gradients are present. Is it the consequence of the presence of an early stage of an OCP ecosystem, or rather its differential efficiency due to edaphic an/or climatic factors? Further work is needed to explore this aspect.

Consequences of an efficient oxalogenic-oxalotrophic ecosystem on nutrient supply

From an agricultural point of view, and if $\mathrm{pH}$ conditions described in the present study remain close to the range favorable for plant nutrition (slightly acidic -5.5 to 6.5 ; Delwiche 1983), some major drawbacks can be expected if soil $\mathrm{pH}$ in an OCP system reaches values up to 10 (as observed in Cailleau 2005 for instance). Such a pH can result in important $\mathrm{P}$ immobilization with $\mathrm{Ca}$ or the loss of exchangeable $\mathrm{Mg}$.

In the context of tropical forests growing on highly weathered soils, the OM recycling is of first importance for plant nutrient supply in order to sustain their primary production (Vitousek and Sanford 1986; Zech et al. 1997). However, in the present study, the impact of Corg $_{\text {Tot }}$ is difficult to grasp as two clear trends are observed. First, in the farthest stations (C, D and E), a vertical gradient is clearly visible and this is an expected feature in tropical soils on which vegetation grows. The same trend is present for the other stations (A and B), although less clear. The second trend observed is a 
greater Corg $_{\text {Tot }}$ content close to the iroko tree (stations A and $\mathrm{B}$ ) than at farther stations (stations $\mathrm{C}$ to $\mathrm{E}$ ). As already hypothesized, this trend must be the result of the presence of a hardwood tree (i.e. the iroko tree), which provides a greater amount of wood and bark to the soil (Cailleau et al. 2011) as compared to the surroundings. Both wood and bark are recalcitrant organic tissues (Freschet et al. 2012; Vane et al. 2006). Indeed, the OM input close to the iroko tree is not only composed of easily decayed leafy material, but also by recalcitrant lignin-rich bark and wood tissues. This is likely to have an impact on the overall rate of OM dynamics close to the iroko tree, emphasizing once again its central role. This is even truer at the light of the recent work by Keiluweit et al. (2015). They point out the critical role of oxalic acid (as root exudates) as a key factor positively influencing microbial carbon mineralization (priming effect) through liberating organic compounds from soil aggregates. Moreover, iroko tissues (wood and bark) are known to be rich in $\mathrm{Ca}$ (Cailleau et al. 2005; Campbell and Fisher 1932), which is estimated to slow down the rate of OM turnover. On the other hand, the soil OM decomposition rate, as well as the nutrient release, can potentially increase where $\mathrm{pH}$ increases (Zech et al. 1997). To conclude on the specific aspect of OM distribution, the intricate influences of the source and nature of OM and the soil $\mathrm{pH}$ make it difficult to assess the relative importance of these three different factors on soil OM dynamics in the context of an oxalogenic-oxalotrophic ecosystem. Nevertheless, the iroko tree appears as an essential driver, influencing both the nature and the quantity of OM reaching the forest floor, as well as its dynamics through the soil $\mathrm{pH}$ and the concomitant variation in OM-Ca content. In its immediate surroundings, the role of an oxalogenic-oxalotrophic iroko tree ecosystem is therefore crucial in the supply and availability of some plant nutrients (e.g. Ca, and probably N), as well as for some key components driving the soil fertility (e.g. $\mathrm{pH}$ and $\mathrm{OM}$ ).

\section{Conclusion}

This study proposes a snapshot of the nutrient dynamics in an agroforestry system in tropical Africa, in the particular context of an oxalogenic-oxalotrophic ecosystem associated with a coffee plantation. The studied system shows very clearly that two trends shape the nutrient distributions associated with a single iroko tree. On the one hand, there are distance-dependent exchangeable nutrient gradients driven by the $\mathrm{pH}$ variable (i.e. $\mathrm{Ca}_{\mathrm{e}}$, and $\mathrm{Mg}_{\mathrm{e}}$ ), itself controlled by the oxalogenicoxalotrophic iroko ecosystem. On the other hand, total P and $\mathrm{K}$ distributions are strictly related to depth. Clearly dominated by the inputs of organic matter, this pattern fits to the plant cycling model described by Jobbágy and Jackson (2001). Multifactorial by nature, nutrient distributions depend on the various and combined influences of edaphic conditions (e.g. pH), local organic matter inputs, minerals, and the possible interactions between nutrients (e.g. Ca-P). There is a clear dual influence of factors, (i) organic matter inputs (the main source and flux of nutrients to the soil) and (ii) the $\mathrm{pH}$, a prevalent parameter for soil nutrient dynamics in tropical ecosystems.

This study of an iroko tree specific system should not be seen as a peculiarity of the African tropical forest. Oxalogenic-oxalotrophic ecosystems are not limited to the iroko tree and Africa (Cailleau et al. 2014; Rowley et al. 2017). Further investigation is needed to generalize the implication, as well as to assess the extent, of oxalogenic-oxalotrophic ecosystems on the nutrient cycling in tropical forest ecosystems. Nonetheless, the biogeochemical and ecological conclusions drawn from this study are likely to illustrate a common pattern of forest dynamics in the Tropics in the presence of oxalogenic trees, mostly in highly weathered watersheds.

Acknowledgements The authors would like to thank the two anonymous reviewers for their detailed comments and suggestions for the manuscript. Special thanks also go to the authorities of Mambicham for their authorization to work in their fields. Help with logistics was provided by the Institut de Recherche pour le Développement (IRD) at Yaoundé, Cameroon. Special thanks go to Banabas Cheke (IRD), our guide and driver. Dr. T Adatte and M. J-C Lavanchy performed XRD and XRF analyses, respectively. This work is supported by the Swiss National Science Foundation, grants no CR22I2 137994, PBLAP2 140105, P300P2 147742, the Société Académique Vaudoise, and "Bourses égalités" of the University of Lausanne.

Open Access This article is distributed under the terms of the Creative Commons Attribution 4.0 International License (http:// creativecommons.org/licenses/by/4.0/), which permits unrestricted use, distribution, and reproduction in any medium, provided you give appropriate credit to the original author(s) and the source, provide a link to the Creative Commons license, and indicate if changes were made. 


\section{References}

Acquaye DK (1973) Factors determining the potassium supplying power of soils in Ghana. Proceedings of the 10th Colloquium of the International Potash Institute, Bern 51-67

Adriaens L (1934) A propos de concrétions pierreuses dans le tronc de Chlorophora excelsa Bth. Bull Ag Congo Belge 25(1):86-90

Ahmed MF, Kennedy IR, Choudhury ATMA, Kecskes ML, Deaker R (2008) Phosphorus adsorption in some Australian soils and influence of bacteria on the desorption of phosphorus. Commun Soil Sci Plant Anal 39:1269-1294

Akima H, Gebhardt A, Petzoldt T, Machler M (2009) akima: interpolation of irregularly spaced data. $\mathrm{R}$ package version 0.5-7, http://CRAN.R-project.org/package=akima

Appel C, Ma LQ, Dean Rhue R, Kennelley E (2003) Point of zero charge determination in soils and minerals via traditional methods and detection of electroacoustic mobility. Geoderma 113(1-2):77-93

Augusto L, Ranger J, Binkley D, Rothe A (2002) Impact of several common tree species of European temperate forests on soil fertility. Ann For Sci 59(3):233-253

Balesdent J, Chenu C, Balabane M (2000) Relationship of soil organic matter dynamics to physical protection and tillage. Soil Tillage Res 53:215-230

Belsky AJ, Amundson RG, Duxbury JM, Riha SJ, Ali AR, Mwonga SM (1989) The effect of trees on their physical, chemical, and biological environments in a semi-arid savanna in Kenya. J Appl Ecol 26:1005-1024

Boyer J (1973) Comportement du potassium dans les sols tropicaux cultivés. In: Potassium in tropical crops and soils. Proceedings of the 10th Colloquium of the International Potash Institute, Bern 83-100

Braissant O, Cailleau G, Aragno M, Verrecchia EP (2004) Biologically induced mineralization in the tree Milicia excelsa (Moraceae): its causes and consequences to the environment. Geobiology 2:59-66

Brenac P (1988) Evolution de la végétation et du climat dans l'Ouest-Cameroun entre 25000 et 11000 ans BP. Institut Français de Pondichéry. Travaux Section Science et Technologie, XXV, 91-103

Cailleau G (2005) Cycle du carbone et biominéralisation carbonatée en milieu continental: la diagenèse des phases oxalate-carbonate. PhD dissertation, Université de Neuchâtel, Suisse, 200p

Cailleau G, Braissant O, Verrecchia EP (2004) Biomineralization in plants as a long term carbon sink. Naturwissenschaften 91: 191-194

Cailleau G, Braissant O, Dupraz C, Aragno M, Verrecchia EP (2005) Biologically induced accumulations of $\mathrm{CaCO}_{3}$ in orthox soils of Biga, Ivory Coast. Catena 59:1-17

Cailleau G, Braissant O, Verrecchia EP (2011) Turning sunlight into stone: the oxalate-carbonate pathway in a tropical tree ecosystem. Biogeosciences 8:1755-1767

Cailleau G, Mota M, Bindschedler S, Junier P, Verrecchia EP (2014) Detection of active oxalate-carbonate pathway ecosystems in the Amazon Basin: global implications of a natural potential C sink. Catena 116:132-141
Campbell WG, Fisher RC (1932) The composition and origin of "stone" in Iroko wood (Chlorophora excelsa, Benth. and Hook. f.) Empire For J 11:244-245

Carozzi AV (1967) Recent calcite-cemented sandstone generated by the equatorial tree iroko (Chlorophora excelsa), Daloa. Ivory Coast J Sed Petrol 37(2):597-600

Chan KY, Davey BG, Geering HR (1979) Adsorption of Mg and $\mathrm{Ca}$ by a soil with variable charge. Soil Sci Soc Am J 43:301304

Chapuis-Lardy L, Le Bayon RC, Brossard M, Lopez-Hernandez D, Blanchart E (2011) Role of soil macrofauna in P cycling. In: Bünemann EK, Oberson A, Frossard E (eds) Phosphorus in action - biological processes in soil phosphorus cycling, springer soil biology series 26. Springer, NY, pp 199-213

Čuhel J, Šimek M, Laughlin RJ, Bru D, Chèneby D, Watson CJ, Philippot L (2010) Insights into the effect of soil $\mathrm{pH}$ on $\mathrm{N}_{2} \mathrm{O}$ and $\mathrm{N}_{2}$ emissions and denitrifier community size and activity. Appl Environ Microbiol 76:1870-1878

Delwiche CC (1983) Cycling of elements in the biosphere. In: Läuchli A, Bieleski RL (eds) Encyclopedia of plant physiology, Inorganic plant nutrition, vol 15A. Springer-Verlag, Berlin, pp 212-238

Ehrenfeld JG (2003) Effects of exotic plant invasions on soil nutrient cycling processes. Ecosystems 6:503-523

Ettema CH, Wardle DA (2002) Spatial soil ecology. Trends Ecol Evol 17:177-183

Evans LJ (1989) Chemistry of metal retention by soils - Several processes are explained. Environ Sci Technol 23(9):10461056

Fageria VD (2001) Nutrient interactions in crop plants. J Plant Nutr 24(8):1269-1290

Fitton G (1997) X-Ray fluorescence spectrometry. In: Gill R (ed) Modern analytical geochemistry: an introduction to quantitative chemical analysis for earth, environmental and material scientists. Addison Wesley Longman, UK

Fontes MPF, Weed SB (1996) Phosphate adsorption by clays from Brazilian Oxisols: relationship with specific surface area and mineralogy. Geoderma 72:37-51

Food and Agriculture Organization of the United Nations (FAO) (2006) Guidelines for soil description. FAO, Rome

Freschet GT, Aerts R, Cornelissen JHC (2012) A plant economics spectrum of litter decomposability. Funct Ecol 26:56-65

Frossard E, Brossard M, Hedley MJ, Metherell A (1995) Reactions controlling the cycling of $\mathrm{P}$ in soils. In: Tiessen $\mathrm{H}$ (ed) Phosporus in the global environment: transfers, cycles and management (Scope 54). J. and Sons Ltd., Chichester, pp $107-137$

Gehrke VMR (1962) Distribution of absorbing roots of coffee (Coffea arabica L.) and rubber (Hevea brasiliensis Muell. Arg.) In: Magister Agriculturae (ed) Mixed plantings in two ecological zones of Costa Rica. Tropical center of research and graduate training, Turrialba $117 \mathrm{p}$

Hobbie SE, Reich PB, Oleksyn J, Ogdahl M, Zytkowiak R, Hale C, Karolewski P (2006) Tree species effects on decomposition and forest floor dynamics in a common garden. Ecology 87:2288-2297

Hoogmoed M, Cunningham SC, Baker PJ, Beringer J, Cavagnaro TR (2014) Is there more soil carbon under nitrogen-fixing trees than under non-nitrogen-fixing trees in mixed-species restoration plantings? Agric Ecosyst Environ 188:80-84 
Hinsinger P (2001) Bioavailability of soil inorganic P in the rhizosphere as affected by root-induced chemical changes: a review. Plant Soil 237:173-195

Husson F, Josse J, Lê S, Mazet J (2014) FactoMineR: multivariate exploratory data analysis and data mining with $\mathrm{R}$. R package version 1.26. http://CRAN.R-project.org/package= FactoMineR

IUSS Working Group WRB (2006) World reference base for soil resources 2006, 2nd edn. World soil resources reports No. 103. FAO, Rome $132 \mathrm{p}$

Jobbágy EG, Jackson RB (2001) The distribution of soil nutrients with depth: global patterns and the imprint of plants. Biogeochemistry 53:51-77

Keiluweit M, Bougoure JJ, Nico PS, Pett-Ridge J, Weber PK, Kleber M (2015) Mineral protection of soil carbon counteracted by root exudates. Nat Clim Chang 5(6):588-595

Kellman MC (1979) Soil enrichment by neotropical savanna trees. J Ecol 67:565-577

Lanfranchi R, Schwartz D (eds) (1990) Paysages quaternaires de l'Afrique Centrale Atlantique. ORSTOM, collection Didactiques, Paris 535p

Le Maréchal A (1976) Carte géologique de l'ouest du Cameroun et de l'Adamaoua : carte $\mathrm{n}^{\circ} 1$. In Géologie et géochimie des sources thermominérales du Cameroun / par Le Maréchal A; [illustrée par] Danard M - Paris (FRA) : ORSTOM, Office de la recherche scientifique et technique outre-mer, 1975. -1 : $1000000\left(\mathrm{E} 8^{\circ} 40^{\prime} 00^{\prime \prime}-\mathrm{E} 15^{\circ} 20^{\prime} 00^{\prime \prime} / \mathrm{N} 8^{\circ}-\mathrm{N} 4^{\circ}\right)$

Li J, Zhao C, Zhu H, Li Y, Wang F (2007) Effect of plant species on shrub fertile island at an oasis-desert ecotone in the South Junggar Basin, China. J Arid Environ 71(4):350-361

Martin G, Guggiari M, Bravo D, Zopfi J, Cailleau G, Aragno M, Job D, Verrecchia EP, Junier P (2012) Fungi, bacteria and soil $\mathrm{pH}$ : the oxalate-carbonate pathway as a model for metabolic interaction. Environ Microbiol 14:2960-2970

Miller AJ, EAG S, Chadwick OA (2001) Redox control of phosphorus pools in Hawaiian montane forest soils. Geoderma 102:219-237

Oertli JJ (2008) Soil fertility. In: Chesworth W (ed) Encyclopedia of soil science. Springer, Netherlands, pp 656-668

Olivry JC (1976) Régime hydrologique en pays Bamiléké (Cameroun). Cahier ORSTOM, série. Hydrologie, XIII, $n^{\circ} 1$

Pansu M, Gautheyrou J (2006) Handbook of soil analysis - mineralogical, organic and inorganic methods. Springer Verlag, Berlin 995 pp

Pathak AN, Kalra YP (1971) Antagonism between potassium, calcium and magnesium in several varieties of hybrid corn. Z Pflanzenernähr Bodenkd 130:118-124

Petschick R (2001) http://www.geologie.uni-frankfurt. de/Staff/Homepages/Petschick/Classicsoftware.html

Poss R, Fardeau JC, Saragoni H, Quantin P (1991) Potassium release and fixation in ferralsols oxisols from southern Togo. J Soil Sci 42(4):649-660

Potter KM, Woodall CW (2014) Does biodiversity make a difference? Relationships between species richness, evolutionary diversity, and aboveground live tree biomass across US forests. For Ecol Manag 321:117-129

R Development Core Team (2012) R: a language and environment for statistical computing. R Foundation for Statistical Computing, Vienna ISBN 3-900051-07-0. http://www.R-project.org/

Raven PH, Evert RF, Eichhorn SE (2000) Biologie végétale. De Boeck Université, Bruxelles, 944p
Resh SC, Binkley D, Parrotta JA (2002) Greater soil carbon sequestration under nitrogen-fixing trees compared with Eucalyptus species. Ecosystems 5:217-231

Retallack GJ (1990) Soil of the past: an introduction to paleopedology. Unwin-Hyman Ltd, London

Rowley MC, Estrada-Medina H, Tzec-Gamboa M, Rozin A, Cailleau G, Verrecchia E, Green I (2017) Moving carbon between spheres, the potential oxalate-carbonate pathway of Brosimum alicastrum Sw.; Moraceae. Plant Soil 412:465479. https://doi.org/10.1007/s11104-016-3135-3

Saetre P (1998) Decomposition, microbial community structure, and earthworm effects along a birch-spruce soil gradient. Ecology 79:834-846

Schneider A, Tesileanu R, Raphaël C, Sokrat S (2013) Kinetics of soil potassium sorption-desorption and fixation. Commun Soil Sci Plant Anal 44:837-849

Schoeneberger PJ, Wysocki DA, Benham EC, Soil Survey Staff (2012) Field book for describing and sampling soils, Version 3.0. Natural Ressources Conservation Service, National Soil Survey Center, Lincoln 300p

Soil Survey Staff (1999) Soil taxonomy: a basic system of soil classification for making and interpreting soil surveys. 2nd edition. Natural Resources Conservation Service. U.S. Department of Agriculture Handbook, Washington DC, p 436 886p

Sparks DL (2000) Bioavailability of soil potassium, D-38-D-52. In: Sumner ME (ed) Handbook of soil science. CRC Press, Boca Raton

Van Bergen PF, Nott CJ, Bull ID, Poulton PR, Evershed RP (1998) Organic geochemical studies of soils from the Rothamsted classical experiments-IV. Preliminary results from a study of the effect of soil $\mathrm{pH}$ on organic matter decay. Org Geochem 29(2-7):1779-1795

Vane CH, Drage TC, Snape CE (2006) Bark decay by the whiterot fungus Lentinula edodes: Polysaccharide loss, lignin resistance and the unmasking of suberin. Int Biodeterior Biodegrad 57(1):14-23

Verrecchia EP, Braissant O, Cailleau G (2006) The oxalate-carbonate pathway in soil carbon storage: the role of fungi and oxalotrophic bacteria. In: Gadd GM (ed) Fungi in the biogeochemical cycles. Cambridge University Press, Cambridge, pp 289-310

Vesterdal L, Clarke N, Sigurdsson BD, Gundersen P (2013) Do tree species influence soil carbon stocks in temperate and boreal forests? For Ecol Manag 309:4-18

Vitousek PM (1984) Litterfall, nutrient cycling, and nutrient limitation in tropical forests. Ecology 65:285-298

Vitousek PM, Sanford RE (1986) Nutrient cycling in moist tropical forests. Annu Rev Ecol Syst 17:137-167

Vogel AW (1994) Compatibility of soil analytical data: determinations of cation exchange capacity, organic carbon, soil reaction, bulk density, and volume percent of water at selected $\mathrm{pF}$ values by different methods. Working Paper 94/07. ISRIC, Wageningen, the Netherlands (http://www.isric. org/documents/document-type/isric-report-199407compability-soil-analytical-data)

Wezel A, Rajot J-L, Herbrig C (2000) Influence of shrubs on soil characteristics and their function in Sahelian agro-ecosystems in semi-arid Niger. J Arid Environ 44:383-398

Zech W, Senesi N, Guggenberger G, Kaiser K, Lehmann J, Miano TM, Miltner A, Schroth G (1997) Factors controlling humification and mineralization of soil organic matter in the tropics. Geoderma 79:117-161 